\title{
MENINJAU ULANG METODE TEOLOGI PRAKTIKA DALAM KARYA ILMIAH DI BIDANG PENDIDIKAN TEOLOGI
}

\section{Casthelia Kartika}

Teologi Praktika adalah sebuah bidang ilmu dalam disiplin ilmu teologi yang pernah menduduki posisi sangat penting karena memiliki relasi-relasi dengan berbagai disiplin ilmu, baik dalam ilmu teologi itu sendiri maupun bidang ilmu lainnya. Dalam sebuah ulasan penting tentang pembagian ilmu teologi, Schleiermacher menyusun disiplin ilmu teologi menjadi tiga bagian besar (dengan memakai analogi pohon), yakni: teologi filosofis, teologi historis, dan teologi praktika. Di bagian dasar/akar pohon, ditempatkanlah Teologi Filosofis yang membahas hal-hal esensi, tentang konsep dan prinsip-prinsip utama, atau dengan kata lain "Ide" dari Kekristenan (seringkali disebut sebagai the root of all theology). Di bagian batang 
tubuh dari pohon, ditempatkanlah Teologi Historika, termasuk di dalamnya studi biblika, sejarah gereja, dogmatika atau teologi sistematika, merupakan penelusuran ke dalam komunitas iman Kristen, dahulu dan sekarang (seringkali disebut sebagai the trunk of theological studies). Sedangkan di bagian paling atas yakni dedaunan dan buah, ditempatkanlah Teologi Praktika, yang merupakan disiplin ilmu yang dilihat sebagai sebuah organisme yang hidup karena banyak membicarakan praksis kehidupan komunitas iman (seringkali disebut sebagai the crown of theological studies). ${ }^{1}$ Melihat analogi ini, tentulah dapat dipahami bahwa Teologi Praktika berposisi dimana buah dari sebuah pohon dapat ditemukan. Seharusnya tempat itu merupakan bagian yang paling terasa hidup dan bergerak dinamis. Namun dalam perkembangannya, Teologi Praktika mendapat banyak sorotan yang cenderung negatif dan bahkan diangkap sebagai ilmu minor dalam teologi.

Disandingkannya istilah "praktika" dengan "teologi" sangat mungkin menimbulkan kecenderungan kekeliruan dalam pemaknaan terhadap istilah "teologi praktika" itu sendiri. Istilah "praktika" atau "praktis" seringkali dimaknai sebagai pelaksanaan konkrit yang tidak mengarah pada dunia konseptual atau teori yang lebih bersifat abstrak. Untuk waktu yang cukup lama penamaan Teologi Praktika mengundang kesalah-mengertian yang tidak sederhana. Hal ini terjadi ketika kata "praktika" dilihat sebagai

1. Jeanne Stevenson-Moessner, Prelude to Practical Theology: Variations on Theory and Practice (Nashville: Abingdon, 2008), 5-6. 
lawan dari kata "teoretika," karena memang secara umum dipahami bahwa praktik adalah lawan dari teori. ${ }^{2}$ Sehingga akibatnya adalah kebanyakan orang melihat Teologi Praktika sebagai ilmu pragmatis yang lebih menuntut pembuktian-pembuktian yang bersifat empiris daripada melihat Teologi Praktika sebagai bidang partikular ilmu Teologi yang menuntut pemahaman, teori dan konsep dasar sebagai ilmu dengan latar belakang pemahaman teologis-filosofis. Kesalahan-kesalahan dalam pemahaman konsep (miskonsepsi) terhadap Teologi Praktika akan memberikan penyesatan lebih jauh apabila tidak dilakukan pembenahan atau pelurusan terhadap makna yang sesungguhnya.

Cara berpikir semacam ini sangatlah lazim di kalangan pembelajar teologi mengenai Teologi Praktika. Misalnya, kebanyakan orang berpikir bahwa permasalahan yang terjadi dalam komunitas iman merupakan persoalan empiris yang menyebabkan arah penyelesaian yang diperlukan adalah dengan melakukan tindakan-tindakan praktis (modern empirical science) yang dapat langsung dirasakan oleh pengalaman seseorang atau komunitas tersebut. Padahal persoalan dalam komunitas iman, secara prinsip tidak dapat diselesaikan oleh ilmu pengetahuan praktis dengan langkah-langkah penyelesaian tertentu, tetapi harusnya kembali

2. Gerben Heitink, Practical Theology (Michigan: Eerdmans, 1993), 6. Istilah Teologi Praktika ini telah digunakan secara luas dalam skala nasional dan internasional. Di Jerman istilah yang biasa digunakan adalah Praktische Theologie. Sedangkan di Amerika Serikat, penggunakan istilah Practical Theology lebih banyak digantikan dengan istilah Pastoral Theology. [7] 
kepada prinsip dasar tentang komunitas iman itu berdasarkan interpretasi teologis tentang komunitas iman itu sendiri. Maka sebenarnya, dari sejak masa Aquinas sampai Abad Pencerahan (Enlightenment), Teologi Praktika dipahami sebagai aplikasi dari prinsip-prinsip akal budi (reason) kepada pengalaman (experience). Bagi Aquinas, pikiran (the mind) memahami prinsip-prinsip fundamental dari akal budi (reason). Kesadaran (the conscience) menghubungkan antara persepsi, kehendak dan akal budi sehingga memiliki kecenderungan untuk bertindak dengan cara tertentu yakni menerima dengan benar suatu situasi dalam kaitan dengan pengertian yang benar akan prinsip-prinsip dasar etika yang benar pula. ${ }^{3}$ Masih dalam catatan James N. Poling dan Donald E. Miller, masuknya paham skeptisisme dari Hume dan Abad Pencerahan (Enlightenment) menghancurkan kaitan erat antara pemahaman teologi dan aplikasi. Sehingga timbullah banyak ilmu pengetahuan empiris modern (modern empirical science) yang mencoba untuk merasionalisasi pengalaman. Hal ini menjadi masalah baru. Sebagai konsekuensinya, Teologi Praktika sebagai satu kesatuan disiplin ilmu teologi konseptual telah banyak ditinggalkan. Sebagai gantinya, muncullah berbagai disiplin ilmu praktis tentang pelayanan yang sebagian besar di bawah acuan semacam ilmu empiris praktis pada

3. James N. Poling dan Donald E. Miller, Foundations for $a$ Practical Theology of Ministry, (Nashville: Abingdon, 1985), 10. 
umumnya. Sebagai hasilnya, Teologi Praktika telah digantikan oleh sejumlah rangkaian disiplin ilmu pelayanan praktis. ${ }^{4}$

Kekeliruan yang lain dalam memahami Teologi Praktika adalah cara melihat obyek dari disiplin ilmu ini, yaitu sangat sedikit memperlihatkan karakter teologis di dalamnya. Unsur "praktika" yang nampaknya menjadi problem dalam pengistilahan, seharusnya dipahami bukan sebagai obyek disiplin ilmunya. Obyek dari ilmu ini adalah "teori praksis." ${ }^{5}$ Secara khusus Heitink memberi catatan bahwa praxis tidak berarti practice tetapi action, activity. ${ }^{6}$ Bahkan dalam kaitan dengan nama Yunani salah satu kitab dalam Alkitab Perjanjian Baru, Kisah Para Rasul - praxeis apostolōn, yang diartikan dengan tindakan Allah melalui pelayanan dari para rasul; dan Roma 12:4 yang menunjuk pada fungsi yang berbeda (praxeis) dari anggota-anggota gereja sebagai tubuh Kristus. Jadi, Teologi Praktika adalah sebuah disiplin ilmu yang berkaitan dengan aktivitas Allah melalui pelayanan umat manusia. ${ }^{7}$

Tulisan ini juga akan memberikan dasar-dasar pemahaman bagaimana mempelajari Teologi Praktika secara tepat untuk mendapatkan hasil pemikiran dan tindakan yang juga maksimal dan bersifat transformatif. Beberapa tinjauan perlu dilakukan, baik dari

4. Poling, Foundations for a Practical Theology of Ministry, 10.

5. Gerben Heitink, Practical Theology, 7. Istilah the Theorie der Praxis ditemukan dalam catatan mengajar dari Schleiermacher di abad 18.

6. Gerben Heitink, Practical Theology, 7.

7. Gerben Heitink, Practical Theology, 7. 
segi hermeneutik, jenis-jenis pendekatan dalam Teologi Praktika, serta metodenya.

\section{Tinjauan Hermeneutik}

Memahami teologi tidak mungkin terlepas dari sebuah interpretasi. Interpretasi biasanya akan membentuk persepsi. Persepsi dan interpretasi disusun sedemikian rupa bukan sekedar untuk membentuk perspektif terhadap suatu obyek tertentu, tetapi lebih kepada penemuan makna yang mendalam, yang kemudian mendorong lahirnya tindakan atau perbuatan yang benar. Sebagai ilmu atau teori menafsir, hermeneutik biasanya dihubungkan dengan teori menafsirkan teks. Namun dalam perkembangannya, "hermeneutik menjadi sebuah ilmu yang mengalami perluasan, sehingga penafsiran dapat juga dilakukan terhadap fenomena nontekstual, misalnya terkait dengan ekspresi hidup, seperti kata-kata yang diucapkan, bahasa tubuh dan perilaku, serta fenomena historis dan sosial." 8

Dalam Teologi Praktika, teori interpretasi diperhadapkan pada pertanyaan utama berkenaan dengan mediasi antara tradisi dan pengalaman. Bagaimana teks-teks dalam Kitab Suci, yang sangat berguna bagi orang-orang dalam konteks masa lalu, juga dapat dialami dalam konteks masa kini sebagai sesuatu yang menghibur dan membebaskan, serta dapat menjadi sumber inspirasi bagi setiap tindakan atau perilaku? Bagaimana teks-teks itu

8. Gerben Heitink, Practical Theology, 179. 
dapat menolong banyak orang untuk memiliki pengetahuan tentang Allah dan pengetahuan tentang diri mereka sendiri? Bagaimana proses pemahaman ini terjadi melalui mediasi tersebut dapat membawa makna dan perubahan, serta pembaharuan hidup? ${ }^{9}$ Aspek krusial dalam komunitas Kristen justru terletak pada interpretasi teologis. ${ }^{10}$ Teologi menjadi praksis ketika memampukan komunitas tersebut berefleksi atas dan terbimbing perbuatannya oleh tindakan Allah yang berkesinambungan. Di situlah letak peran dari teologi praktika, yaitu ketika dapat memberi jalan keluar atas gap yang terjadi antara kehidupan dalam komunitas dan disiplin ilmu teologi itu sendiri. Akan menjadi problem yang besar apabila disiplin ilmu teologi sepertinya terpisah dan tidak berhubungan satu sama lain dengan kehidupan komunitas Kristen.

Penerapan proses interpretasi dalam Teologi Praktika banyak dipengaruhi oleh metode interpretasi dari teologi, filsafat dan ilmu sosial. Secara partikular teori penafsiran yang digunakan adalah model hermeneutic circle, dimana elemen-elemen penafsirannya untuk mencapai sebuah pengertian/pemaknaan terdiri dari: "prejudgement - observation/experience interpretation/discourse - discovering meaning - action."11 Dalam

9. Gerben Heitink, Practical Theology, 193.

10. Poling, Foundations for aPractical Theology of Ministry, 12.

11. Gerben Heitink, Practical Theology, 197. Heitink mengutip contoh yang diberikan oleh $F$. de Lange yang mengatakan bahwa kisah Rasul Paulus adalah contoh yang baik tentang penerapan hermeneutic circle. Setelah mengalami perjumpaan dengan Kristus di Damascus, Paulus menghadapi tantangan untuk memahami apa yang terjadi pada dirinya. 
melakukan observasi baik terhadap pembacaan yang bersifat tekstual maupun non-tekstual, hal utama yang ditekankan adalah elemen dari konteks kultural atau sosial, meskipun akan muncul ketidakjelasan/bias dalam pengertiannya. Di sinilah tahap prejudgement telah berlangsung. Observasi ini kemudian akan memimpin kepada pengalaman (religius), yang merupakan hasil dari interpretasi khusus dari segmen kecil sebuah realita. Tentu saja hal ini membuka peluang pada unsur subjektivitas yang cukup tinggi. Karena itu, pengertian pribadi yang muncul dalam bentuk subjektivitas harus diuji dengan membandingkan atau mengkorelasikannya dengan pemahaman yang lain, yakni dari unsur historis ataupun sosiologis. Sehingga ketika telah terjadi internalisasi pemahaman, maka akan timbul interaksi simbolik yang

Dia berjumpa dengan sesuatu atau seseorang yang memberikan tuduhan atasnya dan menuntutnya atas perbuatannya; namun pengalamannya akan Kristus adalah lebih penting dibandingkan apapun juga. Produktivitas dan karya kreatif dari Paulus sang Teolog diperlukan agar supaya ia mengetahui apa (atau siapa) yang telah dia alami itu dan apa arti dari pengalaman itu. Jarak antara pengertian kita dan peristiwa perjumpaan Paulus dengan Kristus itu harus dijembatani oleh proses interpretasi. Kita harus memasuki lingkaran pengertian, jika kita ingin bicara penuh makna tentang klaim religius atas peristiwa ini dalam hubungannya dengan kita, dan akhirnya dapat menafsirkan dan mengarahkan sesuai dengan bahasa kita (aplikasi) ... Dalam peristiwa Paulus kita juga melihat bagaimana interpretasi terhadap peristiwa Kristus itu tidak hanya menyentuh kemampuannya untuk membaca dan mengerti tetapi juga mempengaruhi eksistensi dirinya secara total, antara firman (kerygma) dan kehidupan keseharian membantu untuk saling menerangkan, serta tidak terpisah dari keadaan yang unik "di dalam Kristus." Hermeneutik teologi jelas bukanlah sekedar persoalan eksegesis, tetapi juga setidaknya mencakup persoalan etika. [197] 
kemudian masuk ke dalam komunikasi religius. Sampai di sini, mediasi telah mencapai pengalaman spiritual yang kemudian tiba pada penyediaan makna untuk persiapan sebuah tindakan/perbuatan. ${ }^{12}$ Jelas di sini terlihat bahwa hermeneutik menunjuk kepada sebuah proses interpretasi yang membawa kepada pengertian. Jadi dalam hal ini proses hermeneutik sebagai sebuah percakapan, sangatlah penting untuk mencapai kepada pengertian tentang kedalaman iman yang dimiliki seseorang. Selain itu, proses hermeneutik juga penting untuk memahami berbagai perspektif dan makna dari berbagai pemahaman yang kita lawan atau setujui dalam konteks masyarakat yang majemuk ini. ${ }^{13}$

Dapat disimpulkan, pola interpretasi dalam Teologi Praktika berbasis pada situasi yang sedang berlangsung (konteks), yang dipakai sebagai kerangka penemuan makna, lalu menjadi pintu masuk untuk sampai kepada praksis iman dan perbuatan.

\section{Model Pendekatan Teologi Praktika}

Model pendekatan dalam Teologi Praktika merupakan hal yang penting untuk dipahami, karena menyangkut strategi pembelajaran dan orientasi pemikiran sebagai dasar pemaparan deskriptif dari Teologi Praktika. Idealnya, pembagian jenis pendekatan terdiri dari dua aspek besar, yaitu pertama, metode kritik (critical methods) yang digunakan untuk membawa bersama-

12. Gerben Heitink, Practical Theology, 197.

13. Don S. Browning, Religious Ethics and Pastoral Care (Philadelphia: Fortress, 1983), 49. 
sama berbagai interpretasi yang terdapat dalam tradisi Kristen dan budaya. Aspek kedua, hubungan antara gereja dan masyarakat. Relasi antara gereja dan masyarakat dapat dijelaskan sebagai horizon sosial dan konteks lokus dari praksis. ${ }^{14}$

Dalam tipologi metode kritik, ada tiga jenis metode kritik yang biasa dipakai dalam ilmu Teologi Praktika, yaitu: ${ }^{15}$

(1) Critical scientific method, metode ini meletakkan disiplin ilmu sekular sebagai kerangka dan norma bagi teologi praktika, dan tradisi memainkan peran sekunder.

(2) Critical correlational method, metode ini berupaya mencapai dialog kolaboratif antara tradisi Kristen dengan disiplin ilmu sekular yang keduanya dapat saling menantang satu sama lain sehingga dapat berkontribusi baik dalam pernyataan-pernyataan deskriptif ataupun normatif, lalu sampailah kepada pemahaman yang lebih dalam setelah melalui dialog esensial yang setara.

(3) Critical confessional method, metode ini menekankan tradisi Kristen adalah yang utama secara normatif, hermeneutik untuk menafsirkan tradisi itu memagang peranan yang sangat penting, dan disiplin ilmu sekular tidaklah secara utama menempati tempat yang penting, dan ilmu-ilmu sekular digunakan dengan sangat hati-hati agar

14. Poling, Foundations for a Practical Theology of Ministry, 31.

15. Poling, Foundations for a Practical Theology of Ministry, 31. 
meminimalisasi pengaruh norma-norma asing terhadap tradisi Kristen.

Untuk aspek yang kedua, hubungan gereja dan masyarakat, ada berbagai cara untuk mengkarakterisasi hubungan di antara keduanya. Tujuan dari kesinambungan antara gereja dan masyarakat adalah fokus pada gereja sebagai kelompok konkrit dalam pergumulannya untuk tetap menjadi setia di tengah dunia modern ini. Bagaimana gereja dapat secara efektif memberikan pengaruh yang positif bagi masyarakat dunia. Apapun pengaruhnya, tujuannya adalah gereja tetap menjadi pusat komunitas yang membagikan praktik hidupnya secara bersama-sama dan juga bermisi kepada dunia sebagai pengaruh yang menyembuhkan. Misi gereja akan memperkaya dan mentransformasi tatanan sosial masyarakat dengan menjadi bagian dari dialog publik. Gereja harus secara aktif menyampaikan perspektifnya kepada arena publik, dan pasti hal itu beresiko terhadap identitasnya, namun tetap harus dilakukan demi masyarakat dunia dapat mengenal Kristus melalui gereja. ${ }^{16}$

Ada juga sistem lain dalam memahami model pendekatan dalam Teologi Praktika yang dapat memperluas wawasan sehubungan dengan pengenalan terhadap teologi praktika yang dikembangkan oleh Paul Ballard dan John Pritchard dalam buku mereka Practical Theology in Action. Model pertama yang dipaparkan disebut dengan applied theory. Teori ini muncul di

16. Poling, Foundations for a Practical Theology of Ministry, 33-34. 
zaman Pencerahan atau yang sering disebut sebagai zaman yang mengagungkan logika. Kalimat kunci yang muncul pada pemikiran zaman ini adalah "knowledge and truth give power and wisdom." 17 Dalam Teologi Praktika, teori ini muncul dalam dua bentuk. Bentuk pertama adalah melakukan penerapan langsung hasil dari disiplin ilmu sosial ke dalam situasi pastoral. Misalnya, teori konseling Rogerian (teori konseling sekular) dan semua keterampilan dalam ilmu konseling ini dipakai sebagai dasar metodologi pastoral untuk konseling. Bahayanya adalah teori sosial atau psikologi itu akan mendikte dan mengarahkan pola praktik pastoral. Bentuk kedua dari model applied theory adalah model yang lebih dapat diterima secara luas dalam kaitan dengan teologi itu sendiri. Di sini, otoritas dan kebenaran adalah poin pertama yang dibangun, tetapi tidak berlandaskan pada ilmu sosial atau psikologi, namun lebih kepada ilmu teologi itu sendiri yang memimpin. Pandangannya adalah Alkitab sebagai materi yang sangat cukup dalam kaitan dengan iman dan moral, atau sebagai pengajaran yang berotoritas bagi Gereja, atau untuk lingkaran yang lebih liberal, mengatakan bahwa teologi natural dibangun oleh pemikiran logis. Sekali otoritas itu diterima, semua tindakan dan obligasi disimpulkan pada dasar otoritas itu. Misalnya, orang-orang Kristen diharapkan untuk mematuhi perintah Allah, atau tugas pemuridan adalah ketaatan. Maka semua

17. Paul Ballard dan John Pritchard, Practical Theology in Action: Christian Thinking in Service of Church and Society (London: SPCK, 1996), 58. 
penjelasan deskriptif tentang teologi mengarah kepada otoritas itu. Kekuatan dari model ini adalah menempatkan otoritas dengan serius. Kelemahannya adalah prosesnya searah, dari teori ke praktis. Model ini mendahulukan teori, sehingga membuat hal yang praktis hanya semata-mata sebagai turunannya saja. ${ }^{18}$

Ballard dan Pritchard juga memberikan ulasan serta pembagian ekspresi dalam memahami metode kritik korelasi (method of critical correlation). Pendekatan ini pada awalnya berangkat dari metode korelasi dari Paul Tillich, kemudian banyak dikembangkan di wilayah Amerika Utara, secara khusus di Chicago oleh Don Browning. Tillich menyarankan bahwa setiap pertanyaan manusia yang menyangkut makna dan eksistensi, akan menemukan jawabannya dari Injil yang diwahyukan oleh Allah di dalam Kristus. Jadi dialog dirancang berdasarkan pertanyaan dan jawaban; dan jawabannya harus berkorelasi dengan wahyu Allah (revelation). Inilah yang kemudian menjadi ekspresi pertama dalam metode kritik korelasi, dimana pendekatan ini adalah tentang dialog antara situasi saat ini dengan tradisi atau perspektif teologi. Jadi pelaku Teologi Praktika berdiri di antara pemahaman dari hikmat Kekristenan yang didasarkan pada Alkitab dan tradisi, dan realitas saat ini. Metode ini mendialogkan antara Injil dan realitas sosial. Ekspresi kedua dari metode korelasi adalah membawa secara bersama-sama perhatian pada isu pastoral dan etika. Relasi interpersonal adalah hal yang paling esensi dari etika. Sangat jarang

18. Paul Ballard, Practical Theology in Action, 59-60. 
keputusan etis itu ada di garis yang jelas, tetapi lebih kepada bagaimana kita menghargai orang, bagaimana norma dan ekspektasi yang kita miliki satu sama lain, apa yang masyarakat harapkan, dan apa yang sedang kita cari. Perilaku etis bergantung pada kualitas orang: apakah mereka dapat dipercaya, baik, terbuka; atau apakah mereka adalah orang yang licik, pemarah, egois? Tugas Teologi Praktika di sini adalah mewaspadai betapa perbedaanperbedaan level personalitas dan pengalaman jatuh pada situasi tertentu; dan bagaimana kita dapat memiliki pengertian yang lebih baik supaya memampukan orang mengambil keputusan yang lebih Kristiani. Untuk melakukan hal ini, maka kita perlu mengetahui sesuatu yang berkaitan dengan konteks sosial dan personal. Ekspresi ketiga dari metode korelasi adalah berdasarkan pada kemampuan hermeneutik. Hermeneutik adalah proses interpretasi. Terkait dengan korelasi ini, yang lebih diperhatikan adalah bagaimana manusia berkomunikasi, bagaimana sebuah makna, maksud dan kebenaran dapat disampaikan dan dibagikan. Misalnya, terkait dengan penafsiran teks. Teks sebagai produk manusia, dimana satu orang berkomunikasi dengan orang lainnya. Seperti yang telah diketahui, bahwa menafsirkan teks tidak dapat secara lurus dilakukan begitu saja. Ada banyak problem penafsiran, seperti penerjemahan, kesenjangan historis dan kultur, dan sebagainya. Tetapi yang menjadi kewaspadaannya adalah bagaimana kita melihat teks itu, bagaimana teks itu digunakan, apa yang kita cari dari teks tersebut dan dalam otoritas yang seperti apa teks itu 
diberikan. Jadi Alkitab itu dibaca dan ditafsirkan dalam konteks yang kompleks, berbeda, dan dinamis. Melalui pendekatan dengan model hermeneutik, tujuannya adalah menyediakan semacam kerangka untuk melakukan dialog yang penuh makna. Melalui model ini, pelaku teologi praktika diperhadapkan pada pertanyaan, apa yang sedang terjadi di antara dua belah pihak atau lebih dalam level dialog yang berbeda dari segi: kultural, historis, sosial, psikologi, metafisik, etika, dan sebagainya. ${ }^{19}$

Model lain dalam teologi praktika yang digagas oleh Ballard dan Pritchard adalah praxis model dan habitus model. Istilah praksis muncul dalam tradisi Marxist, yang mencoba untuk mengatasi perbedaan rasionalistik antara teori dan praktis. Praksis itu lebih dari praktis, dengan pemahaman tidak ada aktivitas manusia yang bebas dari nilai. Poin utama dari pendekatan ini adalah situasi terkini (present, current situation). Apa yang terjadi hari ini adalah ekspresi dari asumsi-asumsi manusia tentang bagaimana sesuatu seharusnya terjadi. Mungkin contoh paling baik dari metode ini adalah komunitas di Amerika Latin. Alkitab dan sakramen menjadi inspirasi dan pemaknaan tersendiri sehubungan dengan situasi kritis yang mereka hadapi saat itu. Kemiskinan dilihat sebagai ketidakadilan dan pemuridan terjadi dalam pergumulan untuk sebuah perubahan. Inilah yang disebut dengan jantung praktika dari Teologi Pembebasan. Maka melalui pendekatan ini, muncullah ekspresi pemuridan yang radikal di antara orang-orang Injili

19. Paul Ballard, Practical Theology in Action, 62-64. 
konservatif. Kekuatan dari metode ini adalah berjangkar kuat pada hal yang praktis. Aktivitas teologis, termasuk di dalamnya studi teoritis dari Alkitab dan doktrin, dilakukan untuk tujuan praksis. Di sini teologi harus mendengar bagaimana orang-orang mengalami keyakinan/kepercayaannya. Itu sebabnya studi sosiologis dan psikologis mengenai keimanan yang praktis menjadi sangat penting di sini. ${ }^{20}$

Yang terakhir menjadi catatan penting dalam model pendekatan dalam Teologi Praktika adalah model habitus. Habitus berasal dari kata habit, yang berarti sesuatu (kebiasaan) yang dilakukan tanpa berpikir lagi, atau di luar kontrol. Dalam pemikiran etika klasik, habit merupakan sebuah pola pikir (mind-set) yang terbentuk, yang kemudian muncul sebagai sifat dalam diri seseorang, yang keberadaannya didukung oleh pembinaan atau pelatihan yang panjang. Terkait model pendekatan ini, tugas dari Teologi Praktika secara khusus bukan pada penyediaan metodologi dan keterampilan, tetapi melatih pikiran dan hati. Tujuannya adalah membangun Tubuh Kristus. Ini merupakan perjalanan panjang dan terus menerus, yang menuntut kepedulian dan komitmen tinggi dari pelakunya; yang melibatkan bukan hanya faktor intelektual tetapi juga keseluruhan personalitas. Tentang hal ini Ballard dan Pritchard menuliskan,

20. Paul Ballard, Practical Theology in Action, 66-67. 
It is good, therefore, to remember that practical theology is not only about the demands of discipleship and the task of the Church in the world. It is not only about the needs of persons and communities. It is also about oneself, of growing into Christ and of living in the fellowship of saints. It is also about losing oneself in God. ${ }^{21}$

\section{Teologi Praktika dalam Kerangka Tulisan IImiah}

Teologi Praktika adalah ilmu teologi yang sangat beragam bidangnya, sehingga melibatkan begitu banyak pendekatan yang berbeda pula dalam metode penelitiannya. Tentu hal ini dapat membingungkan apabila tidak cukup jelas pemahaman yang dimiliki tentang Teologi Praktika itu sendiri serta berbagai pendekatan yang dapat diterapkan dalam sebuah pemikiran akademik ataupun sebuah karya ilmiah. Kemungkinan untuk jatuh pada melihat isu dalam teologi praktika secara empiric science, hampir tidak terhindarkan. Bahkan hal ini telah menjadi fenomena yang membentuk sikap seorang pelaku atau pembelajar Teologi Praktika dalam melakukan studi terhadap isu-isu di dunia Teologi Praktika.

Beberapa elemen penting dalam pembelajaran Teologi Praktika sebagai disiplin ilmu yang dialektik dan berkorelasi, semestinya dipegang sebagai prinsip dasar dalam melahirkan karyakarya ilmiah yang bertanggungjawab dan bersifat akademik dalam bidang studi Teologi Praktika. Beberapa elemen itu dapat dicatat sebagai berikut: (1) Mampu mendialogkan secara kreatif antara teori dan praktik; (2) Memiliki pemahaman akan tradisi teologi

21. Paul Ballard, Practical Theology in Action, 68-69. 
Kristen yang ada di masa lalu dan melihat korelasinya dengan pengalaman keagamaan yang bersifat kontemporer; (3) Mampu melihat realitas situasional tertentu dan prinsip-prinsip teoretikal umum yang berlaku; (4) Mampu menyeimbangkan apa yang berupa realitas dan apa yang seharusnya terjadi; (5) Mampu membedakan apa yang bersifat deskriptif (what is) dan apa yang bersifat preskriptif (what ought to be); (6) Mampu menafsirkan apa yang berupa teks dan yang berupa non-teks dalam pengalaman saat berlangsung; (7) Mampu mengkorelasikan antara teologi dan disiplin ilmu lain; (8) Mampu mengkorelasikan antara komunitas Kristen dan komunitas/masyarakat dunia di luar Kekristenan. ${ }^{22}$

Dengan menuliskan dan menyampaikan secara tepat dan benar berbagai isu dalam teologi praktika yang banyak menyangkut buah dari kehidupan, berteologi secara praksis, seharusnya ini menjadi terobosan penting dalam keilmuan Teologi Praktika di masa kini dan di masa depan.

22. James Woodward dan Stephen Pattison, ed., The Blackwell Reader in Pastoral and Practical Theology (Oxford: Blackwell, 2000), 16. 